\title{
A GOOD IDEA GONE BAD, OR JUST A BAD IDEA? - THE ESTABLISHMENT OF THE SOLICITORS' FIDELITY GuARANTEE Fund
}

\author{
Mark Lunney*
}

This paper examines the historical development of the Solicitors' Fidelity Guarantee Fund in New Zealand. It traces the series of defalcations from solicitor's trust accounts that occurred during the 1920's and how these events led to some District Law Societies proposing the establishment of a compensation fund. The paper also examines the conflicts that occurred between District Law Societies in deciding whether to support the proposal. The author concludes that these historical origins must be considered before any decision regarding the abolition of the fidelity fund is made.

\section{INTRODUCTION}

There is nothing more certain to make a researcher unpopular than to tell solicitors that the research being undertaken relates to the solicitors' fidelity guarantee fund. It hardly needs mentioning that the very existence of the fund is under threat and practitioners are challenging the equity of making the good pay for the bad. This paper is not concerned with the modern difficulties of the fund but will attempt to explain the reasons behind the establishment of the fund nearly seventy years ago.

It is hoped that an understanding of the historical context of the fidelity guarantee fund may lead to a more informed discussion about the future of the fund in the modern legal profession.

* Lecturer in Law, King's College London. The writer would like to thank the New Zealand Law Society, and the Wellington and Auckland District Law Societies for access to their records, in particular Margaret Stewart (NZLS), David Clarke (WDLS) and Luda Donald (ADLS).Thanks are also due to the staffs of the Alexander Turnbull, Parliamentary, New Zealand Law Society and the Auckland Public libraries. Marie Pool kindly read and commented on the draft of this article for which I am most grateful; any errors that remain are those of the author. 
In particular, the paper is not attempting to attribute blame to any individuals in relation to the introduction of the fidelity guarantee fund. No doubt many of the legal practitioners who opposed the fund did so with irreproachable motives, and equally there were many practitioners who positively believed that the fund was a good idea. What this paper will suggest, however, is that the introduction of the fidelity fund was the result of a series of defalcations by solicitors which caused public confidence in solicitors to fall and caused legal business to be lost to the Public Trust Office. The fund served as means of restoring public confidence and regaining business. Any discussion of the future of the fund without reference to what it was meant to do when introduced would seem incomplete, and any attempt to dismantle the fund now should at least be made with awareness of the benefits the fund brought when it was introduced as the first measure of its kind in the Commonwealth in 1929.

\section{EARLY DAYS}

It is impossible to say when the idea of a fund to compensate the victims of defalcating solicitors was first mooted. New Zealand was not alone in considering this remedy for defalcating solicitors, but it is clear that, as far as introducing such a fund, New Zealand was in the vanguard. For example, the Law Society of England and Wales had appointed Special Committees in 1900, 1906, 1928 and 1929 to consider, amongst other matters, the introduction of a fund to compensate the victims of fraudulent solicitors. The Law Society actually recommended the introduction of such a fund in 1929 but this was rejected by the provincial law societies in England and Wales, and the fund was not introduced until 1941. ${ }^{1}$ Similarly, the second Commonwealth state to introduce the fund was Queensland, and there is no record of such a fund receiving consideration prior to its introduction in New Zealand.

It is difficult to trace the source of the idea for a defalcation fund. Partnership law provided a kind of guarantee fund, in that partners were liable for partnership debts incurred by other partners, and the House of Lords had imposed a form of fidelity insurance on law firms when they held the principal liable for the fraudulent acts of his managing clerk in Lloyd $v$ Grace Smith $\&$ Co in $1912 .^{2}$ But it seems more likely that the idea of a fund came from fidelity requirements imposed by law on other professions. Land Agents and auctioneers were required by legislation to provide a fidelity guarantee policy to a fixed

1 Solicitors Act 1941, Section 2(1) (UK).

2 Lloyd $v$ Grace Smith \& Co. [1912] A.C. 716. For the importance of this case in relation to fidelity insurance and solicitors generally see "Insurance and the Liability of the Legal Profession: A Case Study" (1995) 16 Journal of Legal History, 94. 
amount. ${ }^{3}$ The bond was made out in favour of the government which could use the amount recovered to compensate any client or customer for any loss sustained by reason of the actions of the auctioneer or agent. ${ }^{4}$ It seems reasonable to assume that when solicitors' fidelity was called into question some similar scheme should have been mooted as a solution.

The first formal record of such a fund being proposed is contained in the Council minutes of the New Zealand Law Society ("the New Zealand Society") of 7 April 1922. The matter arose in the context of considering the audit of solicitors' trust accounts, which had been compulsory since $1913 . .^{5}$ The meeting considered a letter from Mr Oswald Beere, who suggested: 6

...a scheme for the Society through the medium of insurance, to take complete control of the auditing of Solicitors' Trust Accounts, and to found an Assurance Fund to safeguard clients and others.

The issue was referred to a Sub-Committee but it reported that Beere (a member of the Sub-Committee) had told it that the present time was not opportune for pressing the inauguration of the scheme of indemnity insurance and no further discussion of the issue took place. ${ }^{7}$ It is difficult to gauge what support such a proposal might have had, but the Auckland District Law Society ("the Auckland Society") had instructed its representatives to oppose Beere's suggestion and without the support of the largest District Society it would have been difficult to proceed. ${ }^{8}$

No further action was taken by the law societies until four and a half years later. The question of why the Societies finally acted is dealt with in the next section.

\section{FRAUDS AND SOLICITORS}

The period between the rejection of Beere's scheme and the proposals to create a new fidelity guarantee scheme was littered with stories of misappropriation of trust account funds by solicitors. At that time the first step in complaining of professional misconduct against solicitors was to notify the District Law Society in which the solicitor practised.

3 Land Agents Act 1921-2, Section 8, Auctioneers Act 1928 Section 7. The amount of the bond for both occupations was £500. See also Auckland Star, May 2, 1928, pg 6 - Letter to the Editor, "Defaulting Solicitors - A Guarantee Fund" from 'Common Sense'.

4 Above $\mathrm{n} 3$.

5 Law Practitioners Amendment Act 1913 Section 14 (1), (2) and (3).

6 Council of New Zealand Law Society Minutes, April 7, 1922.

7 Council of New Zealand Law Society Minutes, July 14, 1922.

8 Council of Auckland District Law Society Minutes, March 27, 1922. 
The Council minutes for the Auckland Society provide some evidence for the widespread view that solicitors frauds were becoming more prevalent. Several months after Beere's scheme was rejected, the Auckland Society investigated a Mr Burlow for alleged shortages in his firm's trust accounts. ${ }^{9} \mathrm{~F}$ A Bone absconded with trust monies in mid $1923 .{ }^{10} \mathrm{He}$ was arrested late in January $1924^{11}$ and sentenced to three years reformative detention, and was struck off the roll in April 1924. ${ }^{12}$ In 1924, it was resolved to take action to strike off four solicitors for breaches relating to trust accounts. ${ }^{13}$ In 1925, a long correspondence began with E Thurlow Field over "irregular transactions" in his trust account. ${ }^{14}$

More serious were the defalcations of 1926. In June, the Auckland Society resolved that HE Elliot, who had earlier been convicted for failing to have his trust account audited ${ }^{15}$, be struck off the roll for failing to supply an audit certificate for $1925 .{ }^{16}$ The Auckland Society also took action against John Woodley, whose activities had come to the attention of the Solicitor-General. ${ }^{17}$ The first complaint against HK Emmanuel had been lodged in October $1925^{18}$, and by February 1926 the Auckland Society had resolved to strike him from the roll after a report into his trust account. ${ }^{19}$

However, it was not just the District Law Societies that were noticing an increase in the number of solicitors in trouble with their trust accounts. The press began to take a keen interest in the affairs of lawyers and legal firms from the beginning of 1926. The New Zealand Herald, for example, reported the Magistrates Court proceedings in the Elliot

9 Council of Auckland District Law Society Minutes, March 16, 1 May, 8 May, 5 June, 4 September, 2 October, 9 October, 4 December 1922, 25 March 1923. It was finally resolved that no further action be taken on 2 June, 1924.

10 Council of Auckland District Law Society Minutes, 25 May, 1923.

11 Council of Auckland District Law Society Minutes, 21 January, 1924.

12 Council of Auckland District Law Society Minutes, April 7, 1924.

13 The solicitors were JL Brady, JL Hanna, LJ Prendergast and FJ Mouat - see Council of Auckland District Law Society Minutes, 1 September, 23 September, 6 October and 1 December, 1924.

14 Council of Auckland District Law Society Minutes, 19 January, 2 February, 9 March, 6 April, 4 May, 7 September 1925, 18 January, 5 February 1926.

15 In fact, he had been convicted four times of this offence, in 1920, 1922, 1925 and in May 1926 New Zealand Herald, May 10, 1926, pg. 10.

16 Council of Auckland District Law Society Minutes, 6 April, 4 May, 11 May, 1 June, 1925, 14 June 1926.

17 Council of Auckland District Law Society Minutes, 5 July, 2 August, 1926.

18 Council of Auckland District Law Society Minutes, 5 October, 1925.

19 Council of Auckland District Law Society Minutes, 2 November, 1925, 1 February, 5 February, 1926. 
case. ${ }^{20}$ NZ Truth had a headline "Where is John Woodley", and followed it with the statement: ${ }^{21}$

There are not a few people in Auckland who would like to know the whereabouts of one John

C. Woodley. Others would be even more pleased to know that certain money they entrusted to him is safe.

The article asserted that Woodley had defaulted on a judgment summons, had recently been the subject of case where his conduct had been criticised by Stringer J, and was keen on "the bright life", the inference being that the bright life had been funded from his clients' money. ${ }^{22}$ In September NZ Truth also reported the case of Eric Donald Ross of Christchurch, who was sentenced to twelve months reformative detention for forgery. ${ }^{23}$ The case that attracted the most public attention was Henry Karo Emmanuel. Emmanuel had been struck off in August 1926, and Herdman J had expressed the view that the police should be informed.$^{24}$ Emmanuel was arrested in Dunedin in early September ${ }^{25}$ and later on that month pleaded guilty to charges of stealing money from clients. ${ }^{26} \mathrm{He}$ was sentenced to five years imprisonment by Herdman J, who commented: ${ }^{27}$

Of the many cases of dishonesty that have come my way this is the most extraordinary. You as a solicitor of this Court stole nearly $£ 6000$, and how you did it is beyond me. Had you been a poverty stricken man you may have been entitled to more sympathy, but you are highly educated, and there is no excuse for you. Not only did you steal from people, but you have dishonoured a great profession. A lawyer knows he is trusted, and to dishonour the profession is to drag it through the mud.

20 New Zealand Herald, May 10, 1926, 10.

21 NZ Truth, August 12, 1926, 5.

22 Above n 21, 5.

23 NZ Truth, September 16, 1926, 6. He was already serving a prison sentence for an earlier conviction for theft.

24 Council of Auckland District Law Society Minutes, August 9, 1926. After some uncertainty it was established that the Auckland Society did not need to inform the police - see Council of Auckland District Law Society Minutes, August 9, September 6, 1926.

25 Evening Post, September 1, 1926, 18.

26 The Dominion, September 24, 1926, 10.

27 Evening Post, September 29, 1926, 13. 
More poor publicity followed. E Thurlow Field was finally suspended from practice for five years in October $1926^{28}$, and four other solicitors were prosecuted for failing to have their trust accounts audited. ${ }^{29}$

\section{SOMETHING MUST BE DONE}

The press was quick to point out that something needed to be done to prevent solicitors from misappropriating trust funds. The day after Woodley and Emmanuel were struck off, the Auckland Star editorial noted that these two cases followed a number of similar instances, and that the rules relating to auditing of trust accounts needed to be tightened. Where a solicitor was himself dishonest, the problem was more difficult but had to be solved, as many people "who in the past believed their declining years were safe from want have found that their life savings have been swept away through the dishonesty of a trusted solicitor". If trust account auditing would not work, "a guarantee fund should be built up from which those who suffer can be reimbursed." 30 A Letter to the Editor of October 11 also favoured a kind of guarantee fund, suggesting that a solicitor should provide a bond which was to be proportionately increased as the trust fund grew, and was to be adjusted by a return sent to the Government and certified to by an accountant every half year. Tightening up the audit of trust accounts would not work because "no amount of tightening up the audit system... is going to stop the dishonest solicitor or his employee from gaining his end if once he has set his mind on wrongdoing." ${ }^{11}$ Another correspondent to the Auckland Star went further, favouring the provision of a bond, by all solicitors through an insurance company, for $£ 5000$ as a condition of admission. The letter also referred to frauds by stock brokers and pointedly noted, "Up to the present time there has been no sign of any movement to protect the investing public either by the Law Society or the Stock Exchange of the Dominion." 32 Another version of this idea was suggested by a correspondent to the New Zealand Herald, who argued that Parliament should pass an Act prohibiting anyone other that an authorised court official or special bank officer from receiving or paying trust moneys, and that the receivers of the trust funds be responsible to the parties concerned, for

28 New Zealand Herald, October 20, 1926, 14.

29 J.M.Tudhope (New Zealand Herald, October 23, 1926, 15), A.R.Gorrie (New Zealand Herald, November 6, 1926, 17), George Portas (NZ Truth, November 18, 1926, 10), and John Munro Gillies (New Zealand Herald, November 16, 1926, 15). Gillies, from Dunedin, apparently had a deficiency of $£ 570$ in his account, no cheques had been written into any account books since 1922 nor had any books been kept since then. He also had no system of recording receipts and no blocks of receipt books had been kept. See also NZ Truth, December 2, 1926, 5 .

30 Auckland Star, October 7, 1926, 7.

31 Auckland Star, October 11, 1926, 7, Letter to the Editor from "Audit Clerk".

32 Auckland Star, October 15, 1926, 11, Letter to the Editor from "Investor". 
which service a reasonable fixed scale of charges should be allowed. ${ }^{33} \mathrm{NZ}$ Truth suggested a different solution. The paper noted that the existing protection provided by the audit of trust accounts "does not, however, amount to much...", and that the solicitor "out to rob his client is in no way hampered by the Government audit." Whilst acknowledging that the proposal for solicitors to provide a fidelity bond, or to deposit funds with the Public Trustee, would provide protection, it commented that: ${ }^{34}$

Undeniably it would have the effect of making the legal profession a close corporation, open only to those with wealth to back up their intellectual claims.

The paper suggested one solution - an increase in the penalty for those found guilty of misappropriation. This was required because the offences for which the sentences were being imposed "were becoming an everyday occurrence". ${ }^{35}$ Even the staid Auckland Weekly News felt that some action was required, although the idea of a guarantee fund was rejected as it penalised honest men like no other profession did. Its solution was to ensure that by training, education, and a high and proper feeling in the ranks of the profession itself, only men capable and worthy of trust were admitted to the roll. ${ }^{36}$

It is impossible to know what the profession made of these happenings. However, from the information available it seems that, originally at least, the scandals were not seen as requiring any specific action. For example, the Emmanuel case caused little concern. Fortnightly Notes (the forerunner of the New Zealand Law Journal) thought the case revealed "that a young and apparently inexperienced man has manipulated trust funds improperly". Such events would be reduced when the new examination regulations were felt, as then "only the men keen in the profession, with the interest and honour attaching to the profession at heart, will follow it as a means of livelihood." ${ }^{37}$ The journal felt confident enough in its review of the 1926 year to state that "despite several defaulcations [sic] which received their full measure of publicity it is probable that the standard of the integrity of the Profession has been high, or maybe higher, than that of any other section of the community". 38

33 New Zealand Herald, November 29, 1926, 6, Letter to the Editor from "Lex".

34 NZ Truth, November 1925, 5.

35 Above $n$ 34, 5.

36 Auckland Weekly News, December 2, 1926, 15.

37 Butterworth's Fortnightly Notes, (1926-7) Vol. 2, 469. The journal had expressed similar views before - see Butterworth's Fortnightly Notes, (1926-7) Vol. 2, 373.

38 Above n 37, 541 (December 21, 1926). 


\section{A TIME FOR ACTION?}

Thus the law societies, despite the adverse press criticism, may have felt confident that nothing was required to be done. However, the threat of Parliamentary action could not be dismissed as easily. At the end of the 1926 session Mr Veitch, MP for Wanganui, asked the Minister for Justice whether, during the recess, he would draft legislation providing for the law to be amended to protect people who suffered loss through defalcations of solicitors. ${ }^{39}$ The Minister replied that as the law already provided for audit of solicitors' trust accounts it was difficult to see what further legislation could be introduced, but that any reasonable suggestion would be considered. ${ }^{40}$

It appears as though the possibility of Parliamentary intervention spurred the Wellington District Law Society ("the Wellington Society") into action. On 10 November 1926, the Council of the Wellington Society had its attention drawn to the problem of defalcating solicitors, ${ }^{41}$ and at the next meeting of the Council in January 1927, it was resolved that the matter was worthy of a special meeting ${ }^{42}$, called five days later. This initiative appears to have come entirely from the Wellington Society. It is difficult to see why this should have been so, as there had been only one serious case of professional misconduct involving a Wellington solicitor in $1926 .{ }^{43}$ Perhaps the proximity of the Wellington Society to Parliament put it in a much better position to understand just how likely or not it was that Parliament would intervene. This view is supported by the minutes of the special meeting of 31 January 1927. The President of the Wellington Society, A.W. Blair, stated at the start of the meeting: ${ }^{44}$

It will perhaps be convenient if I indicate shortly the various methods that occur to me as feasible in dealing with this subject (defalcating solicitors). I start off with the assumption that it is highly probable that if no move is made by the Law Societies a move will be made either by the Government or some independent member. It would be highly undesirable that the move should come from other than the Law Society. (emphasis added)

39 NZPD (1926) Vol. 211, 624. A note to the question stated that there had been a number of cases of great loss and hardship of late, and the proposed amendment of the law was required in the joint interests of the profession and the public.

40 Above $n 39$.

41 Council of Wellington District Law Society, 10 November, 1926.

42 Council of Wellington District Law Society, January 26, 1927.

43 That of W.H.Tustin - see Council of Wellington District Law Society Minutes, August 26, 10 November 1926.

44 Council of Wellington District Law Society Minutes, January 31, 1927. 
Blair went on to outline four possible schemes. The first was that arrangements could be made with an insurance company whereby the company undertook responsibility for the fidelity of solicitors joining the scheme. It would be left to individual solicitors to decide if they wished to join the scheme but those who did join would be able to advertise that fact and there would be a consequent loss of business to those who did not join. The main criticism "from the Government's point of view" was that this scheme would not include all firms, "and it is rather the outside firms than the inside firms that have recently been causing trouble." 45 The second proposal was a modification of the first, with the individuals and firms who elected to join the scheme acting as mutual insurers (effectively forming a new insurance company). A problem of both these schemes was that no-one knew how much such a scheme would cost. The third proposal was that each practising solicitor provide a fidelity bond from an insurance company for $£ 2000 .{ }^{46}$ The fourth proposal was that the Law Practitioners Act be amended by providing for an increase of the practising fee of $£ 5$ which would be paid into an assurance fund, and in case of default by any practising solicitor resort could be had to the fund to make good the defalcation. The "serious objection" to this scheme was that "honest men are paying for the rogues." 47 Blair noted that he had proposed a scheme similar to the first proposal when Beere first put forward his scheme but that the New Zealand Society had thought no suitable scheme could be suggested. Things had changed: ${ }^{48}$

The present position, however, would seem to be that if some scheme is not suggested, then the matter will be taken out of our hands.

After discussion, the fourth proposal was adopted and referred to a Sub-Committee, which reported five days later, presenting the meeting with a draft amendment to the Law Practitioners Act. The Council resolved to place the amendment before the New Zealand Society with instructions to its representatives to vote in favour of the proposal. ${ }^{49}$ The comments of Blair and the speed at which the proposals were passed suggest that the Wellington Society knew that action was going to be taken by the Government if no action

45 Above $n 44$.

46 Above $n$ 44. It was estimated that this would add an extra $£ 10$ a year to the cost of a practising fee.

47 Above $n 44$.

48 Above $\mathbf{n} 44$.

49 Council of Wellington District Law Society Minutes, February 4, 1927. 
was taken by the law societies. This idea was taken up by the New Zealand Society when the scheme was placed before it in March 1927:50

He [the President] specially referred to the fact that the scheme could hardly be regarded in the nature of a surprise for the reason that reference had been made in Parliament only last session to the matter of defaulting solicitors and that the Attorney General in dealing with the question in the House had referred to the system of Audit in operation relating to Solicitors Trust Accounts. Furthermore, the Attorney General had very recently informed the President and Vice President that he thought the New Zealand Society should take the initiative in introducing legislation on the subject, otherwise the Government might consider it desirable to take some action.

Pressure was coming from other sources as well. In February the Secretary of the New Zealand Chamber of Commerce wrote to the New Zealand Society pointing out that a resolution had been passed at the Chamber's conference requesting the Law Society to provide adequate indemnity insurance or to establish a guarantee fund in respect of trust monies. ${ }^{51}$ The President had felt the need to tell the Chamber of Commerce that an indemnity fund was under consideration.

After discussion, Blair's proposals and the matter of amending legislation was referred to a Sub-Committee of the New Zealand Society. ${ }^{52}$ On 10 May 1927 the Sub-Committee met with the Attorney-General and discussed the Bill, and the Attorney General replied in detail, arguing that the Bill should be introduced by a private member and be referred to a Committee of the House..$^{53}$

However, it is clear that the Auckland Society were not in favour of such a scheme. Before the March meeting of the New Zealand Society, the Council of the Auckland Society instructed its delegates to oppose the Wellington scheme and to recommend instead that the whole question be referred to a Sub-Committee. ${ }^{54}$ After the New Zealand Society decided to put the issue of amending legislation to a Sub-Committee, the Auckland Society specifically empowered its President to call a special general meeting if he thought fit upon receipt of further information from the New Zealand Society. ${ }^{55}$ In July the Auckland Council sent a telegram (not a letter) to the President of the New Zealand Society to receive an assurance

50 Council of New Zealand Law Society Minutes, 25 March, 1927.

51 Above $n 44$.

52 Above $\mathrm{n} 44$.

53 Council of New Zealand Law Society Minutes, September 3, 1927.

54 Council of Auckland District Law Society Minutes, March 14, 1927.

55 Council of Auckland District Law Society Minutes, April 4, 1927. 
that the recommendations of the Sub-Committee would be submitted to the District Law Societies before anything definite was done. ${ }^{56}$

When the New Zealand Society met in September, enough doubt had been created that the Auckland Society's motion to defer the matter was carried, although the postponement was only until the next meeting or sooner if "a more urgent consideration of the matter was necessary". 57

The issue was again discussed at the Council of the New Zealand Society in early October. This time the divisions were clearer. The President of the Taranaki District Law Society called on the District Societies to again consider the proposal, whilst other members suggested nothing would be gained by pushing the matter on and, in any case, that it was too late for any legislation to be introduced in $1927 .{ }^{58}$ It was suggested by Myers (Gisborne District Law Society) and ultimately resolved that a special meeting of the New Zealand Society be called to consider the matter on 2 December, with each District Law Society sending delegates. Prior to the meeting the President of the New Zealand Society would draft a memorandum setting out the various options and this would form the basis for discussion. 59

The prospect of a final decision on the guarantee fund brought immediate action. The President of the Auckland Society now decided that the time had come for a special general meeting on the topic, which was held on 18 November $1927 .{ }^{60}$ The meeting was extremely well attended, ${ }^{61}$ and the members left no doubt as to what they thought of the proposal by the resolution that was passed, with only three dissentients: ${ }^{62}$

That this meeting of local practitioners condemns the principle of the draft bill as wrong, illogical and unjust and proposes that all available constitutional means be adopted and pursued to oppose the promotion of such bill or the introduction of any similar legislation and that the delegates to the special meeting of the New Zealand Law Society on the 2nd be instructed accordingly.

56 Council of Auckland District Law Society Minutes, July 4, 1927.

57 Council of New Zealand Law Society Minutes, September 3, 1927.

58 Council of New Zealand Law Society Minutes, October 7, 1927.

59 Above $\mathbf{n} 58$.

60 Minutes of General Meetings - Auckland District Law Society. The proposed amending legislation introducing the fund was the only item on the agenda.

61 Above n 60. 121 members of the Auckland Society attended.

62 Above $\mathrm{n} 60$. 
Perhaps recognising that the dismissal of the proposed legislation might be misinterpreted, a resolution was passed unanimously that the Auckland Society would welcome and heartily support any investigation with a view to adopting measures to "prevent the evil which has prompted the proposed legislation".63

All of this was in stark contrast to the actions of the Council of the Wellington Society. On 18 November the Council appointed delegates to attend the special meeting of the New Zealand Society with specific instructions to vote in favour of the bill with power to determine in what form the bill should be presented to Parliament. ${ }^{64}$

The stage was set for a showdown at the Council meeting of the New Zealand Law Society on December 2.

\section{AUCKLAND V WELLINGTON - ROUND 1}

At the December meeting Blair spoke to his proposal, finishing with a proposed resolution that, in principle, the necessary steps be taken to obtain legislation to ensure the fidelity of solicitors. ${ }^{65}$ This was followed by each delegate presenting his Society's view. Before a final vote of the delegates was taken, however, Myers, a Gisborne delegate, suggested that a better way to proceed would be to consider the votes of delegates as the vote of each member of the District Law Society which that delegate represented, and in that way the views of the profession as a whole might be ascertained. Calculated in this way the approximate numbers were 919 against and 731 in favour, and Myers suggested that, given these numbers and the views expressed at the meeting, Blair might ask for leave to withdraw the motion. ${ }^{66}$ Blair agreed that the figures on their face indicated the proposal should not be proceeded with, and withdrew the motion. No further discussion of the issue took place.

It is impossible to know why this kind of voting was preferred, but Auckland had the largest number of practitioners of any District Law Society (510 - Wellington was next largest with 323) so this effectively made Auckland's vote count for more than it would have done in a direct vote by the delegates. It should be noted, however, that six of the eleven District Societies present voted "against" the proposal so the Auckland Society's stance would probably have succeeded anyway. However, the different method of voting may have been one of the "constitutional" methods by which the amending legislation was to be opposed.

Above $\mathbf{n} 60$.

Council of Wellington District Law Society Minutes, November 18, 1927. 
In any event, the position of the Auckland Society prevailed. No further date was set for discussing the issue and at the end of 1927 there appeared little prospect of the introduction of a fidelity guarantee fund for solicitors. The Government had also seemed to lose interest in the matter. Yet six months later such a fund had been agreed in principle. Among the most important reasons for the change of heart was the legal profession's continuing suspicion of the Public Trust Office.

\section{PUBLIC ENEMY NUMBER ONE}

Any consideration of the actions of the professional bodies of lawyers during this period is incomplete without considering the role of the Public Trust Office. Set up in 1872, this statutory body performed a wide variety of legal functions, its most important being the administration of deceased estates. During the period from the middle of 1926 to the creation of the fund, at least as much energy was used to curb the increasing power of the Public Trust Office as was used in the attempt to provide a solution to solicitor's defalcations. The two problems were also linked, because decreasing public confidence in solicitors would or might lead to an increase in business for the Public Trust Office since this provided a clear alternative to using a solicitor to administer an estate. The Public Trust Office, although denying that it was trying to increase business as a result of the scandals, did appear to use the defalcations to its advantage. For example, when NZ Truth published an editorial on the defalcations in November 1926, the Public Trust advertised in bold type at the top of the same page that: ${ }^{67}$

THE FIDELITY AND INTEGRITY OF THE PUBLIC TRUSTEE AND OF ALL OFFICERS EMPLOYED BY HIM ARE GUARANTEED BY THE STATE.

The reaction of solicitors to this type of advertising was to go on the attack. The Fortnightly Notes for the end of 1926 and for 1927 contain a string of critical comments on the Public Trust Office. One correspondent, accepting that the Office fulfilled a need, thought the real peril of the Office was "the Prussian outlook on life" of the officials who regarded "any criticism of the office as a species of sedition...". 68 "Rusticus" wrote in May 1927 that something had to be done about the activities of the Public Trust Office "unless the profession, on its solicitor side, is content to have itself become a department of State". He

67 NZ Truth, November 25, 1926, 5.

68 Butterworth's Fortnightly Notes, (1926-27) Vol. 2, 473 (September 28, 1926). The latter suggestion (that the Public Trustee punished critics) caused Fortnightly Notes to punish an apology for that suggestion the next issue - see Butterworth's Fortnightly Notes, (1926-7) Vol. 2, 481 (October 12, 1926). 
went further, "There is scarcely a Public Trust advertisement which does not contain some veiled allusion to the uselessness or wickedness of the legal profession generally".69

However, it was the public perception of the Public Trust Office that most bothered the legal profession. In May 1927 the Mercantile Gazette was able to comment that the "success of a great public department of State [the Public Trust Office]...is a matter of importance to every citizen who takes an interest in the welfare of his country." 70 Reporting on the business of the Public Trust Office for 1927, the same journal, in an editorial that deserves complete reproduction, offered both praise for the Office and a veiled attack on its main critics, the solicitors: ${ }^{71}$

The success of the Public Trust Office has not been brought about by congratulations in the House, nor by eulogistic articles in the daily journals, nor has it been retarded by unfavourable Press criticism; it rests upon the growing confidence of the community, brought about by the favourable comments of those who have done business with the Department, and who have not hesitated to publish to their friends that they have been fairly treated. We hold no special brief for the Public Trustee or the great institution under his charge, but we are among those who think that everything should be judged by its merits, and believe that where business is continually increasing there cannot be very much wrong. As a matter of fact, we know of no specific case of real grievance, and if any existed, the news would soon spread, and think that a great public debate which is identified so closely with the weal or woe of thousands of the people is entitled, if its business is satisfactorily conducted, to receive reasonable support. Those who believe that there is no serious cause for criticism in the manner in which the multifarious departments of the Public Trust Office are carried on are doing a public duty by placing before the people facts which show that allegations which have been made against the Public Trustee and his conduct of the business administered by him - although, perhaps, made in good faith - are not based upon facts, but upon information which if it were tested by cross-examination would prove incapable of sustaining the allegations which have been made.

The scope of this success can be seen in the growth of business undertaken by the Office. Between March 1926 and March 1927, the Office undertook the administration of 3,581 new estates with assets valued at $£ 5,551,019 .^{72}$ This was the first time the value of new

69 Butterworth's Fortnightly Notes, (1927-8) Vol. 3, 86 (May 24, 1927). Unfortunately, the contributor was made to eat his words when the Public Trustee wrote to the journal to advise that for several years the advertisements had been approved by a representative of the New Zealand Law Society - Butterworth's Fortnightly Notes, (1927-8) Vol. 3, 95 (June 7, 1927).

70 Mercantile Gazette, May 25, 1927, 880.

71 Mercantile Gazette, October 12, 1927, 1769.

72 New Zealand Herald, October 14, 1927, 12. 
estates under administration had topped $£ 5,000,000 .{ }^{73}$ At the end of March 1927 the total value of the estates under administration was $£ 41,043,523$. Worse news for the practising profession was that the Office held a total number of 53,531 wills with a staggering estimated value of assets of over $£ 200,000,000 .{ }^{74}$ When the figures were announced several members of the House paid tribute to the work of the Office.

It was difficult for the law societies to know what to do about such favourable comment. ${ }^{75}$ One possibility was to suggest that there was no "level playing field" between solicitors and the Public Trust Office. For example, F D O'Halloran, a former employee of the Office, in a series of three articles for Fortnightly Notes ${ }^{76}$ sought to show, in the words of the editor, that "private practitioners in Law and Banking 'derive their full working expenses and profits from those members of the public who receive the benefit of their services, and in addition, pay their full share of all forms of taxation', whereas the Public Trustee is subsidised by the State ie the general taxpayer." ${ }^{17}$ Such a rationale for the lower professional fees charged by the Office was needed by solicitors to justify the discrepancy in fees between the private profession and the Public Trustee.

However, one group of practitioners, rather than oppose the Public Trust Office, saw the solution in taking steps to combat the inroads being made on the work of the profession. ${ }^{78}$ In this sense, a broad link can be seen between the proponents of the solicitors' fidelity guarantee fund and the Public Trust Office. Solicitors had to defend themselves in the public eye, and the solicitors' fidelity guarantee fund was a good way of achieving this. Although the most common suggestion for reform was the creation of a Law Society for solicitors only ${ }^{79}$ (the New Zealand Society and the District Societies represented both branches of the profession) there were practitioners who realised that the guarantee fund might be a good way of restoring public confidence (and business). ${ }^{80}$ This

73 Above $\mathbf{n} 72$.

74 Above $\mathbf{n} 72$.

75 The New Zealand Law Society, for example, decided no response could be made to the Mercantile Gazette's editorial of 25 May, 1927 - see Council of New Zealand Law Society Minutes, July 8, 1927.

76 Butterworth's Fortnightly Notes, (1927-8) Vol. 3, 143 (August 2, 1927), 157 (August 16, 1927$), 169$ (August 30, 1927).

77 Butterworth's Fortnightly Notes, (1927-8) Vol. 3, 126 (July 19, 1927).

78 Butterworth's Fortnightly Notes, (1927-8) Vol. 3, 145 (August 2, 1927), Butterworth's Fortnightly Notes, (1927-8) Vol. 3, 172 (August 30, 1927).

79 Above $\mathbf{n} 78$.

80 Butterworth's Fortnightly Notes, (1927-8) Vol. 3, 85 (May 24, 1927). 
was especially important because the advertising ban on solicitors (but not the Public Trustee) made it difficult for individual solicitors to promote their virtue. ${ }^{81}$

By the end of 1927 no solicitor would perhaps have gone so far as to say that the fidelity guarantee fund should be used as a means of counteracting the increase in business of the Public Trust Office, but this problem was always at the back of the minds of those who made the decisions on the fidelity fund. For example, at the end of 1927 the New Zealand Society had arranged a meeting with the Public Trustee to put to him the large number of complaints it had received from the District Societies relating to professional fees, advertising and the encroachment on solicitor's professional work. ${ }^{82}$ Some parts of the Public Trustee's reply cannot have encouraged the New Zealand Society: ${ }^{83}$

...I regret that I am unable to accept the view that the Law Society has any right to decide as to the extent or nature of the advertising which shall be adopted by the Public Trustee... It is no doubt inevitable that to some extent the interests of the Public Trust Office should come into conflict with those of the legal profession... but at the same time I desire to make it clear that I cannot accept any restrictions which would have the effect of hampering the Office in the conduct of its legitimate business.

However, it was not any sudden threat from the Public Trust Office that sparked the renewed interest in the fidelity fund. It was a more familiar problem.

\section{1928 - THE YEAR OF LIVING DANGEROUSLY}

In retrospect it could not be said that 1927 was a particularly good year for solicitors' reputations. The press reported the suspension of the Auckland solicitor W A Black in March 1927 for "muddling" his accounts, ${ }^{84}$ and took particular interest in the case of John Noden Bullard of Gisborne. Bullard's trust account had showed a deficiency of over $£ 6000$, allegedly caused by his deceased partner's activities, but he himself had paid back $£ 4000$ by the time the application to strike off was heard ${ }^{85}$ Nonetheless the Supreme Court found no alternative to striking off, and Bullard later pleaded guilty to charges of theft by misappropriation and was sentenced to two years imprisonment with hard labour. ${ }^{86}$ James

81 Butterworth's Fortnightly Notes, (1927-8) Vol. 3, 172 (August 30, 1927).

82 Council of New Zealand Law Society Minutes, March 23, 1928.

83 Above $\mathbf{8 2}$.

84 New Zealand Herald, March 25, 1927, 13. The Auckland Society had resolved to strike him off the roll in August 1926 - Council of the Auckland District Law Society Minutes, August 16, November 11926.

85 New Zealand Herald, July 12, 1927, 12.

86 New Zealand Herald, July 23, pg 14, August 20, 1927, 13, August 26, 1927, 11. 
Brady, an ex solicitor known to the Auckland Society, ${ }^{87}$ was charged with theft in August, ${ }^{88}$ and in October the New Zealand Law Society sought to have Frederick Jordan struck off for fraud. The Society failed, but the finding of the Court that Jordan "must have known there was fraud but did not realise the true position" and would therefore "be taught a sufficient lesson by having to pay the costs of the petition" cannot have been perceived as a severe punishment by those who believed defalcating solicitors were dealt with too leniently. ${ }^{89}$

While the scale of these misdeeds did not compare with those of the previous year, it was not a vast improvement. Yet there was no perceived need for some measure to stop the bad publicity, as at the end of December the fidelity fund was defeated at the special meeting of delegates of the New Zealand Law Society.

The minutes of the New Zealand Society make no reference to the fidelity fund until July 1928,90 and those minutes simply state that the President reported on the progress of the bill introducing a Solicitors' Guarantee Fund. On its face this is surprising because the last formal mention of the subject in December 1927 had resulted in an indefinite deferral. Clearly something had caused the New Zealand Society to change its mind, although whatever had happened had occurred since March 1928 as no mention was made of the fund at the Council meeting of the New Zealand Society during that month.

Nothing also appeared to be mentioned at the first Annual Law Conference held in Christchurch in early April 1928. Or was there? Perusal of the reports of The Press (which covered in detail the proceedings of the conference) as well as other national newspapers, and the detailed report in the New Zealand Law Journal make no reference to the fidelity fund. However, the New Zealand Society later claimed that a resolution had been passed at that conference supporting in principle the establishment of the fund. ${ }^{91}$ It is difficult to reconcile this discrepancy. There seems little doubt that the press would have published such a resolution given the prominence of the issue, so this seems to leave only two possibilities. The first is that the New Zealand Society lied and no resolution was passed, and later fabricated the resolution in an attempt to save face. This is possible but unlikely as it would have been to easy to verify whether such a resolution had in fact been passed,

87 Above $\mathbf{n}$.

88 New Zealand Herald, August 16, 1927, 12.

89 New Zealand Herald, October 14, 1927, 12.

90 Council of New Zealand Law Society Minutes, July 6, 1928.

91 Letter from A. Gray, President of the New Zealand Society, in Evening Post, May 10, $1928,10$. 
and the resolution was referred to in Council minutes of District Societies. ${ }^{92}$ The second possibility is that the report of the debate on this issue, including the resolution, was censored. The President of the New Zealand Society had told the delegates at the conference that all work was subject to censorship before appearing in the press. ${ }^{93}$ It would seem unlikely that such a resolution should have been censored (given that it would have received favourable press coverage) but perhaps the debate on the issue revealed such deep divisions within the delegates that it was thought best not to release the resolution. The short term gain in favourable press coverage would have been lost if it later turned out to be impossible to put the resolution into practice. This is all speculation, but in its absence one is left with the spectre that neither the New Zealand Law Journal nor the press thought this issue worth reporting despite the fact that they reported other papers from the conference relating to the legal profession. ${ }^{94}$

The refusal to publicise the resolution of the conference is more surprising given that the legal profession was about to reveal another serious defalcation. On March $221928 \mathrm{~J} \mathrm{H} \mathrm{V}$ Mansill and his auditor walked into the office of the Vice President of the Auckland Society and informed him that there was deficiency in his trust account of between $£ 3000$ and $£ 4000 .{ }^{95} \mathrm{~A}$ special meeting was called for the same day and it was resolved to take action to strike Mansill off the roll of solicitors and to ask for his immediate suspension. ${ }^{96}$ On 20 April he was declared bankrupt, and admitted that over three years he had misappropriated approximately $£ 7500 .{ }^{97}$ An arrest for theft followed shortly thereafter, ${ }^{98}$ and at his appearance before the Magistrates Court it was noted that the defalcations were in excess of $£ 7000 .{ }^{99}$ In mid May 1928, Mansill, who had pleaded guilty to the charges against him, was sentenced to four years reformative detention, ironically by Blair J. ${ }^{100}$

92 Council Of Wellington District Law Society Minutes, May 18, 1928, Council of Auckland District Law Society Minutes, May 7, 1928.

93 (1928-9) 4 NZLJ 44-63 (April 24, 1928).

94 For example, "The Outlook of the Profession" by Myers, and "Inroads on the Work of the Profession" by Lascelles, see (1928-9) 4 NZLJ, 60-62.

95 Council of Auckland District Law Society Minutes, March 22, 1928.

96 Above $\mathbf{n} 95$.

97 New Zealand Herald, April 20, 1928, 13.

98 NZ Truth, April 26, 1928, 7.

99 New Zealand Herald, May 8, 1928, 10.

100 New Zealand Herald, May 15, 1928, 11. Blair, as a Wellington Society delegate, had proposed the guarantee fund which was rejected by the New Zealand Society in December 1927. 
By the time Mansill had been sentenced the whole issue of defalcations by solicitors had been brought to the attention of the public for the second time in eighteen months. The day before Mansill's bankruptcy, NZ Truth's editorial started:101

Misappropriation of trust funds and juggling with trust accounts has become so prevalent among law practitioners in New Zealand that the average citizen wonders when measures more effective than those already embodied in the Law Practitioners' [sic] Act 1908, and its several amendments, will be taken to protect him.

There was no doubt what NZ Truth saw as the solution. Whilst it derided more frequent audits of trust accounts as "a sheer waste of time", it suggested that all but technical breaches of the law relating to trust accounts should result in an automatic suspension of the solicitor. This would lead "to less rascality and legalised robbery" in the legal profession. ${ }^{102}$

At the end of April 1928 Letters to the Editor again began to contain references to solicitors' trust funds. The same correspondent who had written to the Auckland Star in 1926 wrote again to suggest that solicitors be put under a bond, but this time stressed that it was the Law Society which should ensure that such a measure was implemented. ${ }^{103}$ "Common Sense" wrote of the "utter futility of the present system" and that "it is surprising how long suffering the public are over this matter". ${ }^{104}$ While the writer thought that the solution was for the government to licence holders of trust funds and use that revenue to provide a compensation fund, the observations that "the legal profession is the closest trade union in the Dominion" and in particular that "the solicitors themselves are unwise in their opposition to the reform suggested, as under present conditions they are simply driving business to the Public Trustee and the trustee companies" were too close to home for the profession. ${ }^{105}$

Lead articles were also being written about the problem. "Croesus" wrote in the Auckland Star that general confidence in solicitors was shattered. The article criticised the "Law Society" for not taking action to introduce a guarantee fund which would ensure the safety of trust funds. Furthermore, the writer argued that the public required more than "the Law Society simply labelling the defaulter as a disgrace... and the only question seems to be

101 NZ Truth, April 19, 1928, 4.

102 Above $n$ 101. The paper also suggested that, given that it was young practitioners who were responsible for the majority of defalcations, only solicitors with five years practical experience should be allowed to handle trust funds.

103 New Zealand Herald, April 21, 1928, 14.

104 The Dominion, May 2, 1928, pg. 8, Auckland Star, April 23, 1928, 6.

105 Above n 104. 
whether the Law Society will devise a scheme themselves or whether they would prefer to have it done for them." ${ }^{106}$ Some correspondents were even blunter. "Common Sense" did not think it was up to the law societies to devise a scheme for the protection of the public because "...the matter has been considered by the law societies on more than one occasion, and... they have refused to initiate any scheme of fidelity guarantee of their members". ${ }^{107}$ The writer thought the matter must be dealt with by government intervention, by levying a licence on each solicitor to fund a fidelity guarantee scheme. ${ }^{108}$ Others again emphasised the uselessness of the protection provided by trust account audits, ${ }^{109}$ whilst one writer to the Auckland Star thought the only solution was to pay and receive all money directly from the other party's solicitor: ${ }^{110}$

All risks would then become the other fellow's business, and so long as you were careful not to make him your solicitor you would be left with an easy mind about what might happen to your cash.

Some response was needed to this criticism, especially in Auckland where the majority of the defalcations had occurred. ${ }^{111}$ On 30 April 1928 the Auckland Star reported that "a committee of the Legal Practitioners Society of New Zealand" had been set up to consider the matter. Apparently the Auckland Society was not prepared to comment on the insurance scheme proposal as it was before the Committee. This is hardly surprising given the stance that had been taken at the special general meeting only 6 months earlier. However, two Auckland practitioners were prepared to be interviewed, ${ }^{112}$ and they were against the guarantee fund. The solution for these practitioners was to allow Law Society audit of trust accounts and to introduce the English scheme whereby cases of professional misconduct were dealt with internally by a committee of the Law Society. ${ }^{113}$

106 Auckland Star, April 24, 1928, 10.

107 Auckland Star, May 2, 1928, 6.

108 Above n 107.

109 Auckland Star, May 5, 1928, 8, Letter to the Editor from "Outsider", (1928-9) 4 New Zealand Law Journal 133 (June 26, 1928).

110 Auckland Star, May 14, 1928, 6, Letter to the Editor from "Scarecrow".

111 For example, during the period from the end of 1926 to the beginning of 1928 the Wellington Society dealt with only one serious complaint, against H. Linklater - see Council of Wellington District Law Society Minutes, August 19, September 7, 1927; January 31, February 10, 18 May 1928.

112 Messrs H Morpeth and W H Wilson.

113 Auckland Star, April 30, 1928, 16. It seems remarkable that, in the face of allegations that the law societies were taking insufficient steps to protect the public, a suggestion should be made that more disciplinary powers should be exercised internally by the law societies. Such a proposal was 
As if poor press coverage was not enough, in early May 1928 the Public Trust Office reported that a fresh record in business had been set for the year ended 31 March 1928, with 58,065 wills on deposit and nearly 7,000 more expected to be deposited in the following year. ${ }^{114}$ At the end of March 31 1928, assets to be dealt with from wills deposited with the Public Trust Office represented $£ 230,000,000 .{ }^{115}$ These figures represented an increase of $8.5 \%$ in the number of wills deposited from the previous year, and an increase of $15 \%$ in the total assets of estates to be dealt with by the Office. This continuing loss of business must have concerned the law societies, ${ }^{116}$ especially with the news of another major defalcation having just broken.

The day after the Public Trust Office results were published the President of the New Zealand Society, Gray, wrote to several leading newspapers to reply to the criticisms. ${ }^{117}$ He stated that the proposal for a guarantee fund had been under consideration by the New Zealand and District Societies for some time. Although there had been opposition from some of the older members, the principle of a guarantee fund had been approved at the Law Conference in Christchurch and:118

Steps are now being taken to carry these resolutions into effect, and it is hoped that a scheme may be evolved for incorporation in a Bill to be submitted to Parliament which, if passed into law, will ensure clients against such losses as have recently been brought under public notice and which have generally been associated with the doings of younger practitioners lacking in experience and judgment.

A response to the criticisms of the law societies by the New Zealand Society was certainly likely, but some of the assertions in Gray's letter may have come as a surprise to the District Societies. The letter appears to have been the result of "chairman's action", as there is no record of any discussion of the merits or otherwise of a public response to criticism of the law societies in any minutes of the New Zealand or District Societies. For example, the Wellington Society noted a letter sent by Gray to the Society on 8 May setting

never formally discussed as a remedy for defalcating solicitors by either the New Zealand Society or the Auckland or Wellington Societies during this period.

114 The Dominion, May 9, 1928, 10.

115 Above $\mathrm{n} 114$.

116 The scale of the increase in business can be gauged by considering that with the 7000 new wills expected to be deposited in 1928-9, the increase in the number of wills deposited from 1926-7 to $1928-9$ was $21.5 \%$.

117 Evening Post, May 10, 1928, 10, The Dominion, May 10, 1928, 11, New Zealand Herald, 12 May, 1928, 12. The letter was also published in the (1928-9) NZLJ 77 (May 15, 1928).

118 Evening Post, May 10, 1928, 10. Gray's reference to the defalcations being the responsibility of younger solicitors drew some criticism - see The Dominion, May 19, 1928, 11 (Letter to the Editor). 
out the resolution passed in Christchurch. The letter pointed out that the resolution had established a committee whose task it was to formulate a final scheme for a guarantee fund, and that a meeting of that committee was proposed for 25 May. Gray's letter also stated that: ${ }^{119}$

... he [the President] had deemed it advisable to address a communication to each of the daily newspapers in answer to the statements which on their face indicated that the public is taking an interest in the subject; and that they were calculated to create a feeling of hostility to the profession unless some action is taken to counteract the idea that the Law Societies are indifferent to the comments.

There is no doubt that the letter was a complete surprise to the Auckland Society. On 7 May the Council had specifically considered the matter of defalcating solicitors and had resolved to tell correspondents that a sub-committee of the Council had been set up to consider the question and would give consideration to all suggestions. ${ }^{120}$ Four days later the Council was forced to call a special meeting to consider a request from Gray that the Auckland Society pass his letter to the press. ${ }^{121}$ Given the previous stand of the Auckland Society on the introduction of a guarantee fund this must have been a difficult request, but it was resolved to comply with the request (without associating the Council or the Auckland Society with the policy of the letter), and to inform Gray accordingly. ${ }^{122}$ At the same time Gray was asked for further information about the position of the delegates to the meeting on 25 May.

The importance of the issue to the Auckland Society can be seen from the request to Gray that he telegraph the reply, and also from the resolution that the President, after receiving Gray's reply, be empowered to call a general meeting of the Auckland Society prior to the meeting of 25 May. ${ }^{123}$

Reading between the lines, the impression gained is that the Auckland Society felt it had been "stitched up". As noted above, there is no record of the debate on the fidelity fund at the Law Conference in Christchurch, but it seems fairly clear that the Auckland Society did not think that the resolution that was passed committed the Auckland Society to do anything. Technically this was correct; the Law Conference was attended by individuals, not representatives of the District Societies, and any vote by individuals could not bind the

119 Council of Wellington District Law Society Minutes, May 18, 1928.

120 Council of Auckland District Law Society Minutes, May 7, 1928.

121 Council of Auckland District Law Society Minutes, May 11, 1928.

122 Above $\mathbf{n} 121$.

123 Above $\mathbf{n} 121$. 
District Societies. However, once Gray had asked that a letter be published telling the general public that the creation of a guarantee fund was a foregone conclusion and that it was only the form of the fund that required clarification, the Auckland Society was placed in an impossible position. Either it did not agree to publish the letter, which would lead to the conclusion that the Auckland Society was against a compensation fund whereas the rest of New Zealand, where the letter had been published, was in favour. This could only have resulted in worse publicity. However, by agreeing to publish the letter the Auckland Society gave de facto support to the proposal. The public would associate the Auckland Society with the sentiments in the letter regardless of whether the letter was from the Auckland Society or not. As well, Gray, by giving his letter to the Wellington press as soon as it was written so that it would be published immediately, played a political masterstroke, since by the time the Auckland Society came to consider whether to publish the letter it had already been published in Wellington. A large part of New Zealand already thought that a fidelity guarantee fund would be introduced. What else could the Auckland Society do but agree to forward the letter to be published? The request for urgent clarification of the position of the delegates to the meeting of 25 May (which only four days earlier had been referred to as a further meeting that may be called ${ }^{124}$ ) sounds like a worried enquiry as to what, exactly, was going on.

In fact, no special meeting of the Auckland Society was called before the delegates met on May 25. The same day as the meeting a requisition from 22 members of the Auckland Society calling for a special general meeting was received by the Council, but the petitioners were asked to postpone the general meeting until the draft bill was received from Wellington. Although no formal record exists of the debate, if any, at the meeting of delegates on 25 May, this resolution of the Auckland Society, made three days after the meeting of delegates and informed by the report of the Auckland delegate to that meeting, makes it clear that the idea of a fidelity fund introduced by legislation had been accepted, by Auckland as well as by everyone else.

The effect of publicly adopting the principle of a guarantee fund gave the law societies immediate benefit in terms of positive press coverage. "Croesus" wrote in the Auckland Star that it was "very pleasing to know" that the legal profession was to introduce a fidelity fund at once: ${ }^{125}$

This is quite in keeping with the opinion most people entertain regarding the capacity of the fraternity to construct a voluntary scheme, instead of having one forced upon them, as some 
have occasionally suggested. Voluntary action will go a long way towards restoring the confidence which has been so severely shaken...

While not everyone had seen the introduction of the fund as a pressing matter, ${ }^{126}$ there is little doubt, however, that the public statements adopting the fund succeeded in diverting press criticism. From the end of May 1928 the leading newspapers lost interest in the story. Of course, the Bill formally making the required amendments still needed approval by the District Societies but it was a foregone conclusion that the idea of the fund would be approved. The draft Bill was sent to the District Societies in July, and both the Wellington and Auckland Councils approved it in principle, with the Auckland Council resolving that it was satisfied that a strong demand existed throughout New Zealand for the scheme. ${ }^{127} \mathrm{~A}$ special general meeting of the Auckland Society called to discuss the draft Bill, after being urged to fall into line with the other District Societies, resolved that the meeting "gives its support to a measure for guaranteeing the fidelity of solicitors". ${ }^{128}$

Now that the Bill had finally been approved by the District Societies there seemed little point in delaying its introduction. The Taranaki Society, always a supporter of the proposal, decided its Parliamentary members should have the opportunity of hearing arguments in favour of the Bill from the profession before having to discuss it in Parliament, and wrote to other District Societies suggesting they do the same. ${ }^{129}$ Another reason for the rapid introduction of the Bill was renewed concern over the operations of the Public Trust Office. Two papers given to the legal conference in Christchurch in April had drawn attention to the erosion of lawyers work by the Public Trust Office. ${ }^{130}$ In July 1928 the New Zealand Society decided that the practice whereby the President inspected advertisements of the Office should be curtailed as "such approval might be taken as

126 Some of the professional journals were equivocal about the fund. The Mercantile Gazette of New Zealand saw the matter as one for the profession, and while not discrediting the idea of a guarantee fund, felt that the solicitors' profession could be trusted to take steps "guarding its honour and protecting its own interests"(Mercantile Gazette, May 30, 1928, 1005). The journal Accounting Commerce and Insurance, although recognising that some change was needed, would not discuss the "pros and cons" of the scheme (Accounting, Commerce and Insurance, (1928) Vol. 15, No. 2, 46, May 1928)..

127 Council of Wellington District Law Society Minutes, 24 July, 1928, Council of Auckland District Law Society Minutes, 23 July, 1928.

128 Minutes of General Meetings - Auckland District Law Society, 24 July, 1928. There was some defiance - the original resolution proposed that support be given along the general lines set out in the draft bill, but this was not adopted. The discussion of the draft bill also forced the meeting to be adjourned and reconvened on the following day.

129 Council of Wellington District Law Society Minutes, July 24, 1928.

130 M Myers, "The Outlook of the Profession" and Lascelles, "Inroads into the Work of the Profession", (1928-9) 4 NZLJ 44-63. 
expressing the approval of the Society...and that, in point of fact, the Council considered the style of the advertisement in use objectionable". ${ }^{131}$ At the Council meeting of 5 October the President placed a confidential memorandum dealing with Public Trust activities before the Council, and suggested that it go before "the 1928 Committee", a mysterious group that "had already dealt satisfactorily with various cases of interference by Government Departments with private business". ${ }^{132}$ The memorandum was sent out to the District Societies for comment and a committee was established to amend the memorandum as appropriate. ${ }^{133} \mathrm{In}$ September the Annual Report of the Public Trust Office confirmed the figures released in May as to the increase in business, ${ }^{134}$ and in October the Mercantile Gazette again praised the work of the Office, noting that even though its operations adversely affected the legal profession there was still little criticism of the Office (my italics). ${ }^{135}$

It was unfortunate, then, that the first efforts at introducing the Guarantee Fund failed, through no fault of the law societies. After receiving all the comments from the District Societies, it was decided that the bill would be introduced as an amendment to the Law Practitioners Act which would empower the New Zealand Society to establish the scheme, the details to be left to the Society. ${ }^{136}$ This met with the approval of the Attorney General who promised to support the bill, though as a private member and not for the government, ${ }^{137}$ and the bill was introduced in the Legislative Council on August 21, 1928. Eight days later it had its second reading. The bill received generally favourable treatment ${ }^{138}$, except from McIntyre who suggested that it was unfair that the honest lawyer subsidise the dishonest, ${ }^{139}$ although he recognised that "this was a good thing for the Public Trust Office." 140 The bill was passed in the Council the following day, and received its first

131 Council of New Zealand Law Society Minutes, July 6, 1928. The Auckland Society also complained about Public Trust Office advertising - Council of Auckland District Law Society, October 1, 1928.

132 Council of New Zealand Law Society Minutes, October 5, 1928.

133 Council of New Zealand Law Society Minutes, November 20, 1928. See also Council of Wellington District Law Society Minutes, 19 November, 1928, Council of Auckland District Law Society Minutes, 5 November, 1928.

134 New Zealand Herald, September 13, 1928, 15.

135 Mercantile Gazette, October 10, 1928, 1798.

136 Council of New Zealand Law Society Minutes, October 5, 1928.

137 Above $\mathrm{n} 136$.

138 NZPD, (1928) Vol. 218 590-593 (August 29, 1928).

139 See also Letter to the Editor from "Subject" in The Dominion, August 30, 1928, suggesting that the guarantee scheme trespassed on the liberty of the subject.

140 Above n 138, 591. 
reading in the House of Representatives on 11 September. However, despite the confident assertions from the New Zealand Law Journal that the bill would be passed during the current session, ${ }^{141}$ the situation changed as the remaining private members days were appropriated for government business. Even with the Prime Minister giving the bill an opportunity to be read a second time without debate and having it referred to the Statutes Revision Committee, the bill was not allowed to proceed as the Committee felt it required more consideration than could be given to it at that time, and also should be first introduced in the House of Representatives. ${ }^{142}$ The law societies were undoubtedly disappointed that the bill was delayed, ${ }^{143}$ and the New Zealand Law Journal in its review of the year hoped that the new Attorney-General would "believe, as the Profession of which he is the head, that the proposals are in the best interests both of the Profession and of the public, and that nothing is to be gained, but much is to be lost, by further delay."144

\section{A SOLICITORS' FIDELITY GUARANTEE FUND - AT LAST}

The final passing of the Law Practitioners Amendment (Solicitors' Fidelity Guarantee Fund) Act of 1929 is, in one sense, the least important part of the story behind the creation of the fund. The decision to go ahead with the scheme had been made the previous year, and all that was required was to convince a willing Parliament of its merits. Some District Societies had actually pressed for the bill to be presented at the Parliamentary sittings in December 1928 but this was rejected as impractical. ${ }^{145}$ Nonetheless, the attitude of the New Zealand Society was clearly in favour of passing a bill to introduce the fund as soon as possible ${ }^{146}$, and even the Auckland Society resolved, at a special general meeting in March 1929 , to promote a bill to introduce a guarantee fund and in doing so to seek the support of other law societies. ${ }^{147}$ Perhaps the most interesting point is the link that was tangibly drawn between the guarantee fund and the Public Trust Office during this period. The Committee set up by the New Zealand Society to draft a memorandum on complaints against the Public Trust Office reported to a special meeting of the Council of the New Zealand Society in April, 1929. Some of the District Law Societies (Canterbury for one) had

141 (1928-9) NZLJ, 199 (September 4, 1928).

142 Council of New Zealand Law Society Minutes, October 5, 1928.

143 (1928-9) NZLJ, 247 (October 16, 1928).

144 Above n 143, 327 (December 20, 1928).

145 Council of New Zealand Law Society Minutes, March 22, 1929. The Gisborne Society had pressed for the early introduction of the bill, but this was rejected as the parliamentary session in December was only being held because of the change of government that had just occurred.

146 Above $n 145$.

147 Minutes of General Meetings - Auckland District Law Society, 15 March, 1929. 
proposed that consideration of the memorandum be adjourned until the Solicitors' Guarantee Bill was finalised and the Council agreed, resolving to postpone the issue until the guarantee bill "has been satisfactorily dealt with by Parliament". ${ }^{148}$ All copies of the confidential memorandum were recalled. ${ }^{149}$ News, however, had leaked to the Public Trustee and the New Zealand Society was forced to respond to an enquiry in June 1929 as to the status of "the 1928 Committee" and the New Zealand Society's connection with it. ${ }^{150}$ It is impossible to know why the memorandum was recalled at the April meeting but it seems likely that the New Zealand Society wanted to have the guarantee bill in place as a means of rebutting any argument that the Public Trust Office was a safer place for trust monies to be than with solicitors. With the fund in place, the law societies would be in a stronger position to challenge the expansion of the Office's business.

By the time the New Zealand Society replied to the Public Trustee's letter in August, ${ }^{151}$ the guarantee bill had almost been finalised. On 6 May 1929 a delegation from the New Zealand Society met with the new Attorney General, Sidey, and the parliamentary draftsman, and it was agreed that the latter would draft a bill to introduce the fund. ${ }^{152}$ The draft bill was sent to the District Societies in June, and the fund was now so uncontroversial that the two major District Societies, Auckland and Wellington, hardly considered the matter, giving their representatives to the New Zealand Society power to speak for the District Society when the bill was considered by the New Zealand Society. ${ }^{153}$ This occurred in early July, and the meeting authorised the parliamentary draftsman to incorporate agreed amendments into the draft bill. ${ }^{154}$

The Law Practitioners Amendment (Solicitors' Fidelity Guarantee Fund) Bill was introduced into the Legislative Council on August 29, 1929 and had its substantive debate the following day during its second reading. As was indicated by the administrative support given to its drafting, it was a government bill although one that was promoted by the profession. It differed from the bill presented the previous year in that the details of the scheme were set out in the legislation, and that overcame some of the objections to its

148 Council of New Zealand Law Society Minutes, April 26, 1929.

149 Above n 148.

150 Council of New Zealand Law Society Minutes, October 4, 1929.

151 Above $n 150$.

152 Council of New Zealand Law Society Minutes, July 5, 1929.

153 Council of Auckland District Law Society Minutes, July 1, 1929, Council of the Wellington District Law Society Minutes, 28 June, 1929.

154 Council of New Zealand Law Society Minutes, July 5, 1929. 
predecessor. ${ }^{155}$ It was introduced in the Council by the Attorney-General and the principle of the voluntary guarantee fund received praise. ${ }^{156}$ However, McIntyre did point out what he thought was the real reason for the bill: ${ }^{157}$

I admit that in this Bill the legal profession is voluntarily endeavouring to protect the public; but, in claiming credit for it, it was making a virtue of a necessity, because the members of the profession are well aware that, owing to the many defalcations of trust funds by dishonest lawyers a large amount of business is going to the Public Trust Office, and something had to be done to stop it. It is being borne home to the public week after week that at present the safest thing to do is to place trust moneys in the hands of the Public Trustee; and this is an attempt to regain the public confidence...

The Council passed the Bill with only minor amendments, and it had its first reading in the House of Representatives on September 4. Over a month passed before time could be found for the second reading, and even then it was only read pro forma and sent to Committee. Once before the House in the Committee stage (at the end of October), however, a similar pattern to its passage in the Council developed. Introduced for the government by the Minister for Justice (Mr Wilford), the fidelity fund principle received acclamation as a voluntary step by the legal profession to compensate victims of defalcations by solicitors. ${ }^{158}$ Only a couple of members, indirectly, queried just how voluntary the measure had been. The member for Wallace, Mr Hamilton, noted that the measure was necessary "otherwise the profession would ultimately suffer and the business would drift into hands where a greater measure of security was obtainable"159, and $\mathrm{Mr}$ Holland, the member for Buller, while supporting the principle, suggested that anyone who wanted to be perfectly sure about their trust funds might place them with the Public Trustee and "get over this difficulty once and for all". 160 The Bill as amended by the Statutes Revision Committee passed its third reading without incident, and after approval of the amendments without critical comment in the Council, received royal assent on 7 November 1929. New Zealand had created the first fidelity guarantee fund for solicitors in the Commonwealth.

\footnotetext{
155 See McIntyre's comments - NZPD, (1929) Vol. 222, 659 (August 30, 1929)

156 See NZPD, (1929) Vol. 222, 657 (Mr Sidey), 658 (Sir Francis Bell), 660 (Mr Hanan)

157 NZPD, (1929) Vol. 222, 659.

158 NZPD, (1929) Vol. 223, 1027 (Mr Wilford), 1028 (Mr. Broadfoot), 1030 (Mr Downie Stewart, Mr Lysnar), 1031 (Mr Mason, Mr Barnard).
}

159 Above n 158, 1029.

160 Above n 158, 1031. 


\section{CONCLUSION - THE PAST}

The story of the introduction of the fidelity fund can be seen from two perspectives. Firstly, it can be seen through expressed views of the professional lawyers who introduced it - that it was a voluntary fund created by the profession for the benefit of clients. It is suggested that this is inaccurate. Rather, the evidence suggests that the law societies were at least partly motivated to act by public concern over defalcations by solicitors and the extensive press coverage of the subject. This, together with the perceived need of the New Zealand Society to respond to the criticism, indicates that the law societies were reactive rather than proactive. It cannot be denied that the action of the law societies was motivated by self interest, and the rapid change of attitude of the Auckland Society during 1928 can only be explained by reference to the external pressures on the profession.

Similarly, the dramatic growth in business of the Public Trust Office influenced the actions of the law societies. In some of the most lucrative areas of legal practice solicitors did not have a monopoly. They were forced to compete, and one of the services their main competitor could offer was the complete fidelity of its employees. This was insignificant if the fidelity of solicitors was unproblematic; when it became problematic lawyers were forced to react, as a practical means of retaining clients and as a public relations exercise, to both the real and perceived threat of losing clients to a competitor.

However, it would be equally inaccurate to suggest that the only motivation for action by the profession was self interest. The difficulty with such a view is that it assumes the profession spoke with one voice, or acted with one motivation, or that individual solicitors were solely influenced by one factor in deciding whether to introduce the compensation fund. Many solicitors were concerned about the loss of professional reputation that the defalcations caused, and although a loss in reputation by the profession as a whole would have resulted in loss of business, there seems little doubt that professional lawyers wanted to believe that they were practising not in a business but in a profession, engaged in activity that was in the public interest. For that reason clients needed to be protected from the fraudsters, because the work solicitors did benefited not just the solicitor but society as a whole, so that any conduct that made this role less effective should be eradicated or its effects mitigated. The Solicitors Fidelity Guarantee Fund was an attempt at the latter. Of course, the law societies acted with the knowledge that the press was expecting some action to be taken, but, in the end, it was solicitors that brought the changes into effect.

It should also be remembered that the fund was the first of its kind in the common law world. If the profession trod a careful path towards the fund's introduction, it can hardly be blamed as it was entering uncharted waters. Although similar schemes did exist for other occupations, the lawyers who argued for the introduction of the fund deserve credit for taking a bold step. While there seems little doubt that the introduction of the fund was influenced by public opinion, the role of the lawyers should not be forgotten. 


\section{CONCLUSION - THE FUTURE}

Do these conclusions suggest anything as to the future of the fund? Whatever its pitfalls, the fund has good points. Practically, it is a tangible sign that the profession can show to the public to illustrate that the profession does care whether clients' are treated well. As the profession of the late 1920's realised, it was a great public relations device. The press of the 1920 's revelled in revealing how widows and orphans had been left penniless; the fund has prevented this from occurring, at least to the same extent.

The proponents of the fund did not give much thought to what kinds of clients' funds it should cover; they assumed it should apply to all client money. The reasons behind the establishment of the fund tell little about whether fund should or should not apply to specific categories of client money ie investments, money in conveyancing matters. However, one purpose in introducing the fund was to restrict entry to "men capable and worthy of trust". ${ }^{161}$ The problem was that the introduction of the fund or some kind of fidelity bond might have restricted access to the profession to those who could afford to pay the appropriate levy or premium. ${ }^{162}$ Those concerns are no less pertinent today, and if its coverage has been reduced so as to ensure, as far as possible, equality of opportunity to the profession, this would seem desirable so long as the limitations do not amount to reductio ad absurdum.

Perhaps the greatest similarity between opponents of the fund in the 1920's and today is the argument that the fund punishes the good in favour of the bad. ${ }^{163}$ And of all the arguments on the benefits of the fund this one is either unanswerable or irrelevant, depending on your point of view. It was never contested that the fund did impose a cost on honest, competent solicitors. ${ }^{164}$ For some, like the Auckland Society members, this made the fund intolerable. ${ }^{165}$ For others, the cost was worth paying, in terms of public confidence and in preventing inroads into the work of solicitors (particularly relevant in the 1920's due to the growth of the Public Trust Office). ${ }^{166}$ This dilemma remains today - the fund is anti-competitive if viewed in isolation, but can it be used to defend self-regulation and the conveyancing monopoly? The practitioners of the 1920's took the view that, on balance, it

161 Auckland Weekly News, December 2, 1926, 15.

162 NZ Truth, November 25, 1926, 5.

163 Auckland Weekly News, December 2, 1926, 15.

164 For example, Gray, in his letter of 10 May 1928, recognised that some older practitioners might "not unreasonably dislike the notion that the honest many should be required in a sense to guarantee the possibly dishonest few" - The Dominion, May 10, 1928, 10.

165 Minutes of General Meetings - Auckland District Law Society, November 18, 1927.

166 Auckland Star, May 19, 1928, 14 - Article by "Croesus". 
was worth the trade off but it is for every generation of New Zealand practitioners to reevaluate. However, one may question how reticent a modern government would be, in the absence of the fund, to introduce external regulation in the event of a series of defalcations as in the late 1920 's, especially in an age where the practice of law is promoted, both by practitioners and non-lawyers, as a business rather than an "honourable profession". One also wonders what the press would have made of recent scandals had there not been a compensation fund.

The events of the late 1920's were such that lawyers had to act to restore the confidence of the public in the profession. Any public confidence which the profession enjoys today has been retained partly because of the existence of the fund. Ultimately, the lawyers of 1928 and 1929 decided that the profession as a whole should subsidise the defalcating few, for the benefit of the profession as a whole. If this view is to change, the ramifications must be carefully thought out. The fund may still be thought of as "wrong, illogical and unjust", but surely no more wrong and illogical than to discuss the fund without reference to both its past and future role for the practising solicitor in New Zealand. 
(1997) 27 VUWLR 